(Flemish Section). The course itself dealt with humanitarian law, its development and dissemination. Talks were given by professors from the Universities of Leyden and Limburg in the Netherlands and Antwerp, Louvain and Brussels in Belgium, as well as by a representative of the Belgian Ministry of Foreign Affairs and members of the two National Societies which organized the course.

This course was of a high academic level and was greatly appreciated by those who took part. A similar course will be organized in the Netherlands in 1990.

\title{
Death of H.S.H. Princess Gina of Liechtenstein
}

It was with great sorrow that the ICRC learned of the death on 18 October 1989 of Her Serene Highness Princess Gina of Liechtenstein, founder and President from 1945 to 1985 of the Liechtenstein Red Cross.

Her passing deprives the Movement of one of its most eminent figures, whose lifelong devotion to the Red Cross was exemplary.

It was on Princess Gina's initiative that the Liechtenstein Red Cross was created on 30 April 1945 to assist the thousands of refugees fleeing hunger and destruction during the last days of the Second World War. The Princess herself set the example by distributing relief to destitute men, women and children. In the ensuing decades the President of the Liechtenstein Red Cross was often to be found in the front ranks, working with the utmost devotion to help refugees from Hungary in 1956, from Czechoslovakia in 1968 and from Indo-China in 1979.

Princess Gina initiated many humanitarian activities, including development schemes for National Societies, and launched numerous operations to assist the victims of disasters, such as the drought and famine which have afflicted Ethiopia in recent years. She also worked tirelessly for the benefit of handicapped children in Africa.

In her own country, Princess Gina was well known for her child care programmes and her projects to provide medical care for the sick at home and assistance for the elderly.

Her immense contribution to and personal participation in humanitarian activities nationally and internationally and her outstanding dedication to the wounded, the sick and war victims made of her an outstanding champion of the humanitarian cause. 
For all these reasons, in 1987 the Standing Commission of the Red Cross and Red Crescent awarded her the Henry Dunant Medal.

Princess Gina had been Honorary President of the Liechtenstein Red Cross since 1985.

The ICRC was represented by its former President, Mr. Alexandre Hay, at the Princess' funeral on 24 October in Vaduz.

In paying tribute to Princess Gina of Liechtenstein, the ICRC shares her family's deep sorrow and mourns a Red Cross personality of great stature. 